\title{
Teaching Estuarine Hydrology with Online Data
}

\author{
David H. Schoellhamer
}

Received: 19 January 2009/Revised: 7 May 2009 / Accepted: 24 June 2009 /Published online: 11 August 2009

(C) The Author(s) 2009. This article is published with open access at Springerlink.com

\begin{abstract}
The transfigurative development of automated online data sources from estuaries, coastal oceans, and their watersheds provides a tremendous opportunity for use by educators. In this article, one approach tailored for San Francisco Bay and its watershed is presented. Hydrology can broadly be defined as the study of the properties and distribution of water. Multidisciplinary hydrologic characteristics that are exemplified by typical online data include spatial variability, temporal variability, forcing mechanisms, historical context, and extreme events. Data analysis and manuscript preparation allow students to develop and utilize scientific skills such as critical reading of the literature, evaluating data sources and quality, writing and data presentation, and conducting peer review. The goal of this approach is to use recent local real-world data and publication to motivate graduate students to study estuaries and coastal oceans.
\end{abstract}

Keywords Estuaries - Watershed Coastal ocean .

Hydrology · Education · San Francisco Bay .

Multidisciplinary $\cdot$ Online data $\cdot$ Internet

\section{Introduction}

Two developments - automated sensors and the internethave made data plentiful and easily available, fundamentally altering how estuarine and coastal science is con-

\section{H. Schoellhamer $(\triangle)$}

Department of Civil and Environmental Engineering,

University of California, Davis,

1 Shields Avenue,

Davis, CA 95616, USA

e-mail: dschoell@ucdavis.edu ducted. Automated sensors allow (1) long-term (years) collection of temporally high-resolution data to observe relevant physical processes (e.g., tides), (2) collection of spatially high-resolution data to observe gradients (e.g., vertical profiles), and (3) data collection from remote or inaccessible sites in the watershed, estuary, or coastal ocean. The internet distributes these data to the public, allowing greater use by society and scientists from other disciplines, fostering multidisciplinary science.

The editors of Estuaries and Coasts asked me to submit this article describing how I use automated online data to teach estuarine hydrology. A broad definition of hydrology is utilized herein: the properties and distribution of water. The class, Hydrology of San Francisco Bay and Delta, is a multidisciplinary graduate class offered by the Department of Civil and Environmental Engineering at the University of California, Davis. The campus is in the Central Valley of California, which is most of the watershed of San Francisco Bay (Fig. 1). A class project is to write a series of articles on the hydrology of the San Francisco Bay and Delta that are submitted for publication in the Newsletter of the Interagency Ecological Program for the San Francisco Estuary (introductions by Schoellhamer 2007a, b).

The class is intended to motivate students to learn about watersheds, estuaries, and the coastal ocean. The students download, analyze, and interpret real data that describe conditions they are familiar with (i.e., a wet winter) and are from local sites and water bodies that they have seen and are familiar with.

In this paper, I will describe the structure of the class and several multidisciplinary hydrologic characteristics that are exemplified by typical online data: spatial variability, temporal variability, forcing mechanisms, historical context, and events. Examples from class articles will be presented. The class also exposes students to critical reading of 


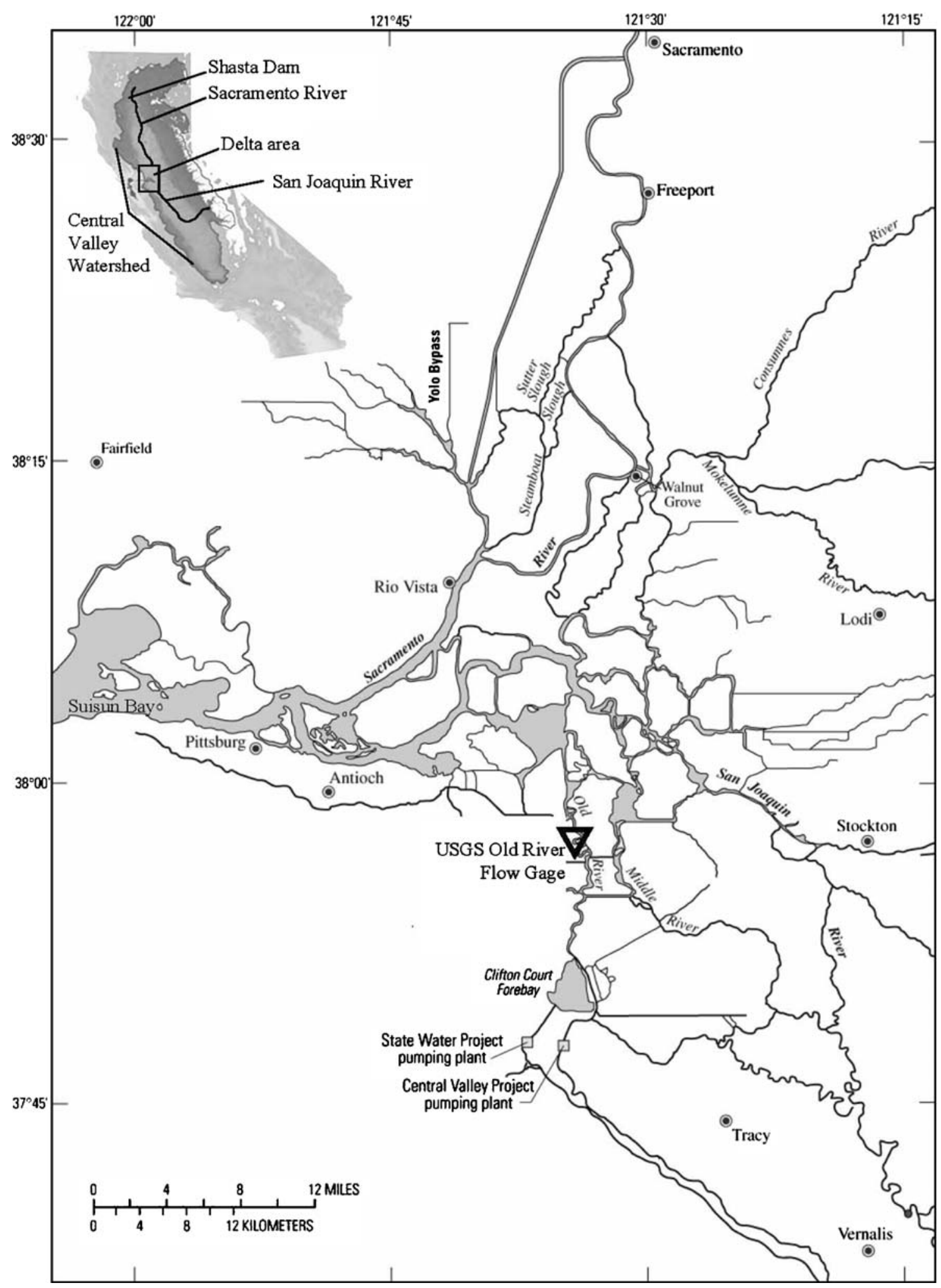

Fig. 1 Sacramento-San Joaquin river delta 
scientific literature, evaluating data sources and quality, scientific writing and data presentation, and conducting peer review.

San Francisco Bay and its watershed are featured because of its proximity, familiarity, ecological and water resource significance, extensive online data sets, and abundance of knowledge available from decades of monitoring and research. The primary headwaters are in the Sierra Nevada Mountains on the east side of the Central Valley. Most of the Central Valley is drained by the Sacramento and San Joaquin Rivers (Fig. 1). The Delta refers to the confluence of the Sacramento and San Joaquin Rivers upstream from the Bay. Seaward from the Delta is the North San Francisco Bay which includes Suisun Bay, Carquinez Strait, and San Pablo Bay (Fig. 2). San Francisco Bay is surrounded by many relatively small watersheds that are drained by local tributaries. Freshwater flow into the South San Francisco Bay comes from local tributaries, not the Central Valley. The North and South Bays meet in Central Bay which is connected to the Pacific Ocean through the Golden Gate.

\section{Class Structure}

The class covers a breadth of topics on San Francisco Bay, its watershed, and the adjacent coastal ocean (Table 1). A guest lecturer or I provide a 1-h lecture on each topic, which generally is about a specific parameter (e.g., salinity) or group of similar parameters (e.g., flows in the Sacramento River watershed). One student is assigned to each of the topics that will be included in the series of short articles. Students' interests are best matched with the topics and essential topics such as freshwater flow and salinity are sure to be included. For each topic that will be the subject of a short article, a homework assignment is given to the entire class to gather data, plot it, and perform some simple statistical analyses. Data used include precipitation, snowpack, dam storage, river discharge, water diversions, coastal upwelling, meteorology, water level, salinity, suspended sediment, temperature, and chlorophyll (Table 1). Depending on the data available for a specific topic, each student is assigned to gather, plot, and analyze data for a particular parameter, watershed basin, measurement station, or year. Guidelines are given so the data are structured somewhat uniformly. Different data sources use different units and the original units are retained so familiar units are presented to readers of the articles. Students post their completed homework on a discussion board for me to grade and to allow the student author to access, compile, plot, and further analyze the data for their article.

Each author writes a short article describing their parameter during the two preceding water years. Articles are typically three paragraphs long and have one or two figures. The combined length is about that of a typical journal article. The articles describe data sources, spatial and temporal variability of the parameter during the water years, and forcing (perhaps merely a reference to a paper on the topic), any unusual occurrences and compare the water years to historical data. California has two distinct hydrologic seasons: a wet season from late autumn to early spring with the remainder of the year being dry. Thus, the water year, which begins on October 1 and ends on September 30 , is a convenient period to study hydrology because it begins in the dry season, includes a single wet season, and ends in the dry season. The first draft is posted on a discussion board and is graded pass/fail. Two other students are assigned to provide a peer review of the draft and I usually provide general comments. The author responds to the review comments and posts a final version of the article. I grade the reviews, author responses, and the final draft. All written communications, except grades, are through class discussion boards. The class and I do a final integration of the articles and I submit them to the Interagency Ecological Program Newsletter, which is published by a group of water resource agencies and is not peer-reviewed. This approach and class product are similar to that described by Bradley et al. (2004) in which students review literature, interview decision makers and scientists about a specific problem, and write short publications about their findings.

Authors also select a peer-reviewed journal article about their topic for the class and I to read. During class, 1 week after the lecture on that topic, the student summarizes the paper for the class and we discuss the article. Each student must make one comment or ask a question that demonstrates that they have read and thought about the paper. The author/presenter is supposed to have a better knowledge of the material and answer questions. If they cannot, I give my best answer. This allows a deeper study of a particular topic than achievable with a 1-h lecture.

Lectures at the end of the class are about multidisciplinary topics such as contaminant and fishery decline that integrate information previously presented in the class. The class also takes a 1-day field trip to visit waterways, measurement stations, and water management structures.

\section{Hydrologic Characteristics}

Physical, chemical, and ecological parameters describe the watershed, estuary, and coastal ocean. Regardless of discipline, parameters describe similar types of hydrologic characteristics that students must grasp in order to understand estuaries. The condition of an estuary varies spatially 


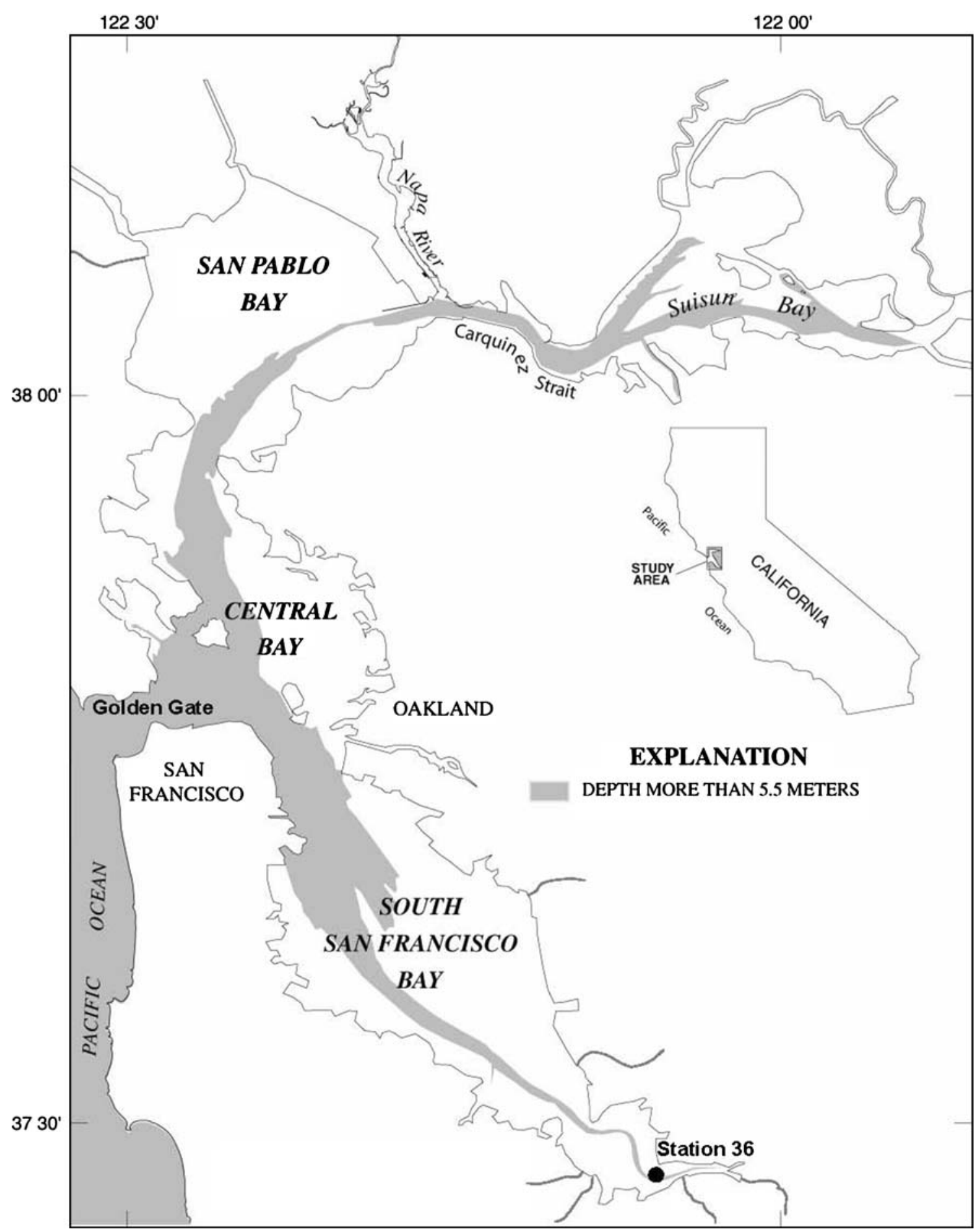

Fig. 2 San Francisco Bay

and changes with time (e.g., salinity). Various forcing mechanisms create this variability (e.g., freshwater inflow and ocean exchange). One or 2 years of data cannot reveal temporal variability at longer timescales (e.g., climate shifts such as El Nino/Southern Oscillation) or whether a minimum or maximum value is a historically extreme event (e.g., floods and droughts), so a longer period of data must be analyzed to provide better historical context. The articles written by the students evaluate the multidisciplinary hydrologic characteristics of temporal variability, spatial variability, forcing mechanisms, historical context, and extreme events for their specific parameters. 
Table 1 Topics, data sources, and websites

\begin{tabular}{|c|c|c|}
\hline Topic & Data source & Data website \\
\hline \multirow[t]{2}{*}{ Precipitation } & CDEC-snowpack & http://cdec.water.ca.gov/cgi-progs/previous/COURSES.html \\
\hline & $\mathrm{CDEC}$-rainfall & http://cdec.water.ca.gov/cgi-progs/previous/PRECIPOUT.BSN \\
\hline \multirow[t]{2}{*}{ Sacramento River flow } & CDEC & http://cdec.water.ca.gov \\
\hline & USGS & http://waterdata.usgs.gov/nwis/sw \\
\hline \multirow[t]{2}{*}{ San Joaquin River flow } & CDEC & http://cdec.water.ca.gov \\
\hline & USGS & http://waterdata.usgs.gov/nwis/sw \\
\hline $\begin{array}{l}\text { San Francisco Bay } \\
\text { tributary flow }\end{array}$ & USGS & http://waterdata.usgs.gov/nwis/sw \\
\hline Delta diversions & DWR & www.iep.ca.gov/dayflow/index.html \\
\hline \multirow[t]{2}{*}{ Delta flows } & DWR—delta outflow & www.iep.ca.gov/dayflow/index.html \\
\hline & USGS-flows in delta & http://waterdata.usgs.gov/nwis/sw \\
\hline \multirow[t]{2}{*}{ Coastal ocean } & NOAA—upwelling & www.pfeg.noaa.gov:16080/products/PFEL/modeled/indices/upwelling/NA/upwell_menu_NA.html \\
\hline & NOAA-temperature & http://seaboard.ndbc.noaa.gov/station_history.php?station=46026 \\
\hline Meteorology & NOAA & www.ncdc.noaa.gov \\
\hline \multirow[t]{2}{*}{ Bay water level } & $\mathrm{CDEC}$ & http://seaboard.ndbc.noaa.gov/station_history.php?station=46026 \\
\hline & NOAA & http://tidesandcurrents.noaa.gov/sfports/sfports.shtml?port=sf \\
\hline \multirow[t]{2}{*}{ Salinity } & CDEC-time series & http://cdec.water.ca.gov \\
\hline & USGS-transects & http://sfbay.wr.usgs.gov/access/wqdata/ \\
\hline Suspended sediment & USGS & http://sfbay.wr.usgs.gov/access/wqdata/ \\
\hline \multirow[t]{2}{*}{ Water temperature } & CDEC-time series & http://cdec.water.ca.gov \\
\hline & USGS-transects & http://sfbay.wr.usgs.gov/access/wqdata/ \\
\hline Chlorophyll & USGS & http://sfbay.wr.usgs.gov/access/wqdata/ \\
\hline
\end{tabular}

CDEC California Data Exchange Center, DWR California Department of Water Resources, NOAA National Oceanic and Atmospheric Administration, USGS US Geological Survey

\section{Spatial Variability}

Common spatial gradients in estuaries are longitudinally from the ocean to river and laterally from a deep channel to shallow water. These gradients provide diverse habitats for the estuarine ecosystem. Transect data are well-suited to describe spatial variability in an estuary.

In San Francisco Bay, examples of longitudinal spatial variability are provided by longitudinal transect data collected during monthly water quality cruises by the US Geological Survey $R V$ Polaris (Table 1). For example, during summer, Pacific Ocean water is relatively cool. Ocean waters mix through the Golden Gate with Central Bay waters, and water temperature increases in the landward direction into the South Bay and San Pablo and Suisun Bays (Fig. 3, Yang 2007). An estuarine turbidity maximum in the North Bay is routinely present (Journet 2007). Salinity stratification is greatest in the North and Central Bays which receive most of the freshwater inflow (Hestir 2007). A spring phytoplankton bloom usually occurs in the South Bay but not in the North Bay, so the maximum chlorophyll-a concentration in the South Bay is about five times greater than in the North Bay (Cheng 2007).

Time series data collected from different stations can also be averaged and compared to determine spatial variability. Mean annual wind speed at an offshore buoy and in the delta was a little more than twice as large as at a station in the South Bay (Weathers 2007). Mean annual water elevation was greatest in South Bay and smallest in Suisun Bay (Noujdina 2007).

In the watershed, precipitation data for individual basins show greater precipitation in the Sacramento Valley compared to the San Joaquin Valley (Guidice 2007). Flow into the bay from local tributaries was only $3.6 \%$ of the total flow volume entering the bay via the Sacramento/San Joaquin River Delta in water year (WY)2005 (Leatherbarrow 2007).

\section{Temporal Variability}

Estuaries are driven by a process that operates at different timescales, from tides that vary every few hours to climate shifts and droughts that vary every few years. Time series data can be used to show temporal variability at different timescales. The primary source for time series data was the California Data Exchange Center (Table 1).

A distinct wet season from November to March and dry season from April to October (Fig. 4, Carr 2007) drives river discharge to the estuary. At higher elevations in the watershed, snow typically accumulates from January to March and melts from April to June (Fig. 5, Carr 2007). River flows are a combination of rainfall and snowmelt signals (Fig. 6, Ross 2007). Reservoir storage peaks near the conclusion of snowmelt and is a minimum at the end of the dry season (Fig. 7, Ross 2007). Within a water year, 
Fig. 3 July 2006, July 2007, and historical July surface temperatures in the San Francisco Estuary (Yang 2007). Data were obtained from http://sfbay.wr. usgs.gov/access/wqdata/

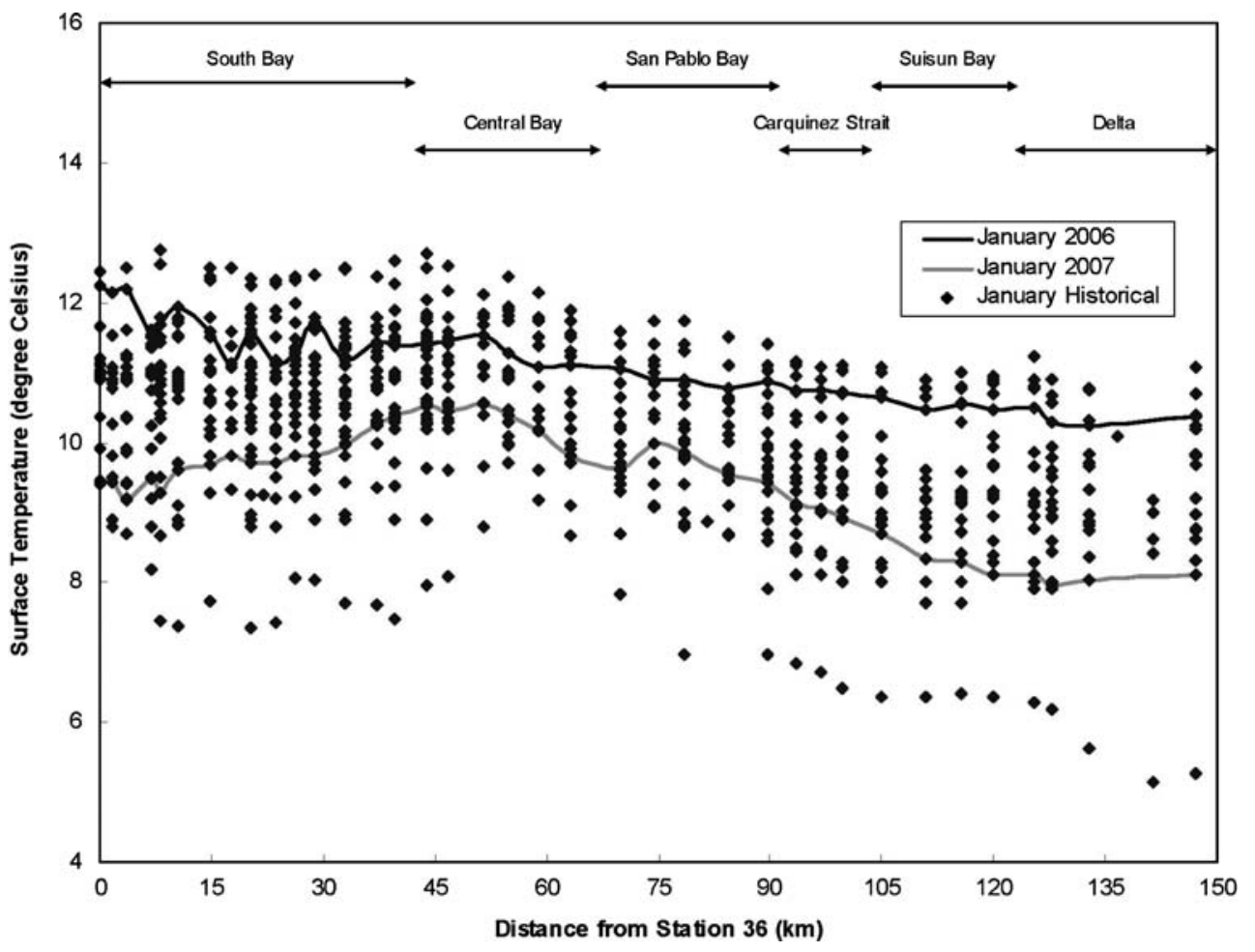

river flow is highly variable so that in a wet year some daily or monthly flows are below normal and in a dry year some daily or monthly flows are above normal (Fig. 6, Ross 2007; Table 2, Zelin 2007).

Comparison of water years can show interannual variability. WY2006 was a wet year compared to WY2007 (Figs. 4 and 5, Carr 2007). For a class assigned to analyze data for WY2006 and WY2007, this was fortuitous and helped demonstrate to the class and readers the differences between wet and dry years. Flows in the Sacramento River were much greater in WY2006 compared to WY2007 (Fig. 6, Ross 2007). For the much smaller local tributaries, mean annual WY 2006 flows were up to almost 12 times greater than in WY2007 (Pan 2007). Water levels in the bay were greater in WY2006 than WY2007 and maximum tidally averaged water levels correspond to maximum freshwater inflow to the bay (Noujdina 2007). Compared to WY2007, salinity was less in WY2006 and vertical salinity stratification was greater (Hestir 2007). In addition, salinity was flushed out of Suisun Bay for almost 3 months during WY2006 but remained for all of WY2007 (Hestir 2007). Greater inflow in WY2006 may account for greater chlorophyll concentrations in South Bay (Cheng 2007).
Fig. 4 Rainfall and historic monthly averages for the period of record for the Sacramento River watershed (Carr 2007). Data were obtained from http:// cdec.water.ca.gov/cgi-progs/ previous/PRECIPOUT.BSN

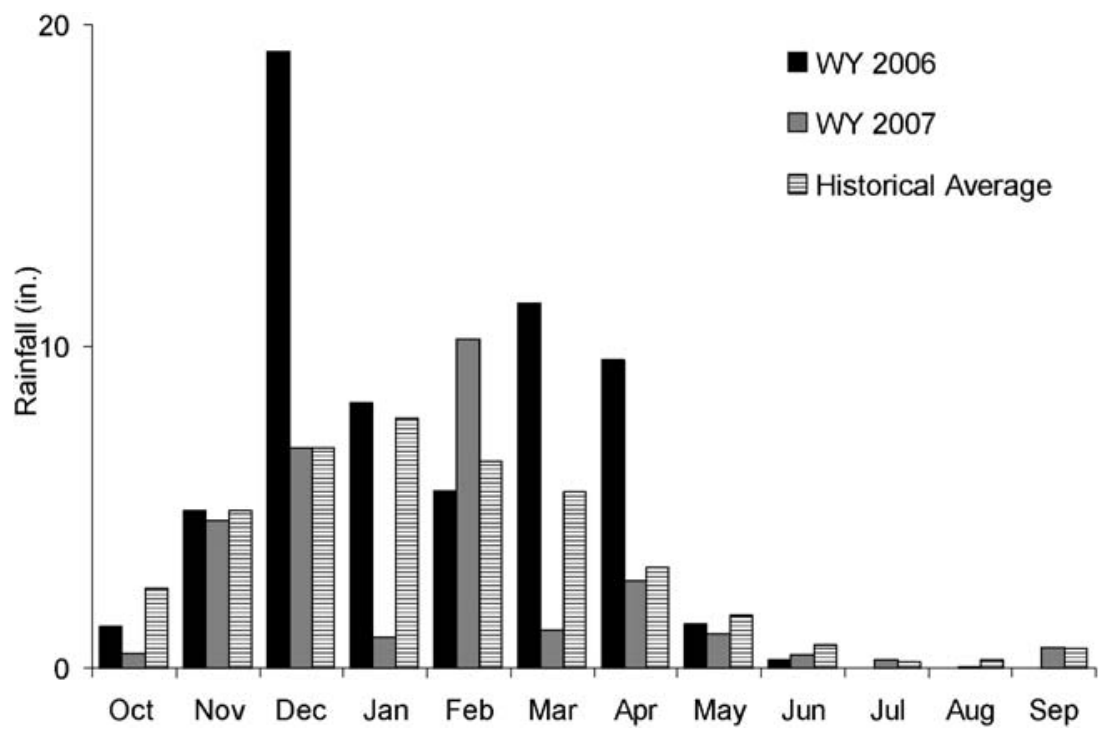


Fig. 5 Unweighted mean of snow water equivalent and historic monthly averages for the period of record for the San Francisco bay watershed. Percentages denote percentage of historic average (Carr 2007). Data were obtained from http:// cdec.water.ca.gov/cgi-progs/ previous/COURSES.html

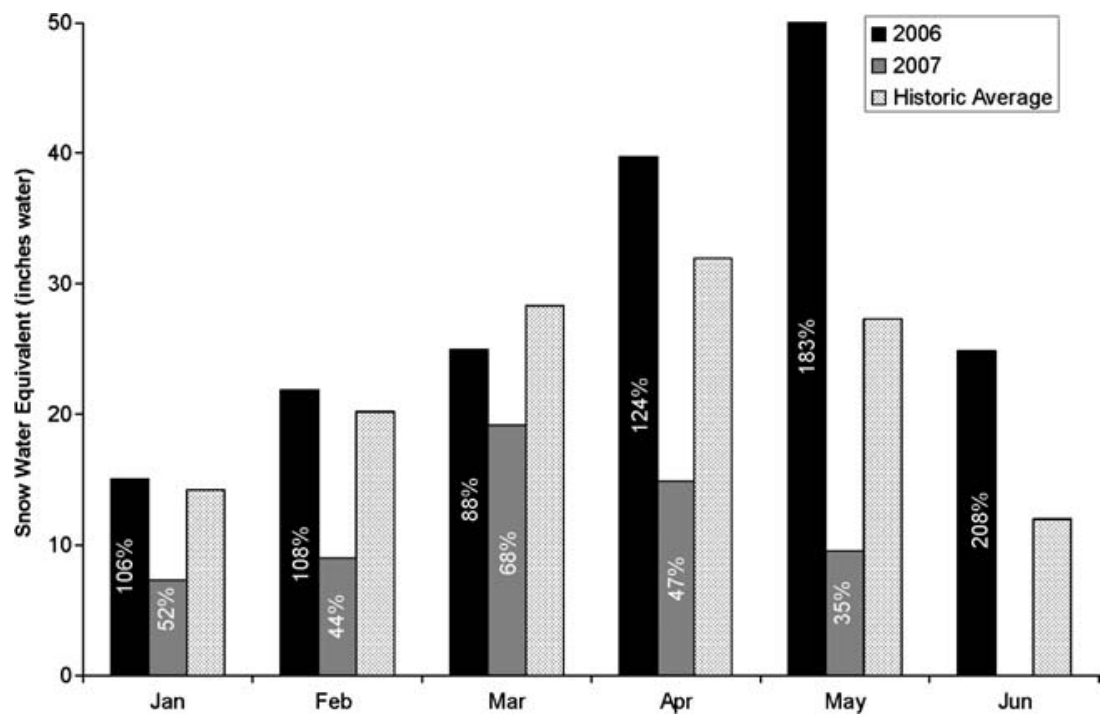

Sensors that record data at least hourly show tidal and diurnal variability. Hourly time series of salinity shown that salinity range in Suisun Bay can be up to 16 during a tidal cycle (Hestir 2007). Diurnal wind variation offshore can be up to $30 \mathrm{mph}$ (Weathers 2007).

Monthly transect data can be used to identify temporal variation in parameters that vary seasonally such as water temperature (Fig. 3, Yang 2007). In addition, transect data can identify some temporal variability for parameters with no continuous time series, such as a spring phytoplankton bloom in South Bay (Cheng 2007).

\section{Forcing Mechanisms}

The effect of forcing mechanisms on parameters can be inferred from data. Not all data can be explained and sometimes data are contradictory. These lessons are rarely found in peer-reviewed literature but often are learned while students are trying to understand and explain a data set.

The strong relation between precipitation, river flow, salinity stratification, and inverse relation with salinity demonstrate that the estuary is connected to its watershed and the atmosphere (Hestir 2007). The largest freshwater flows of WY2007 were during February 2007 and transported sediment to the estuary and increased suspendedsediment concentrations. Overall, greater inflow in WY2006 transported more sediment to the estuary and increased suspended-sediment concentrations compared to WY2007 (White 2007). Greater inflow in WY2006 also may explain greater chlorophyll concentrations in the South Bay (Cheng 2007).

Although less apparent, data demonstrate likely connections between the estuary and ocean. In January, upwelling offshore from the Bay was greater in 2007 than 2006 and water temperature followed the expected inverse relation with the 2006 temperature $1.5^{\circ} \mathrm{C}$ greater than 2007 (Connell 2007). In the Bay, water temperatures were $1-3^{\circ} \mathrm{C}$ greater in 2006 than 2007 (Yang 2007). In July, upwelling offshore from the Bay was greater in 2006 than 2007 but water temperatures were nearly identical in the Bay and offshore. In the Bay, water temperatures were greater in 2006 in some places and less in others. Thus, while there are some clear connections, the students also learn that there are confounding factors that prevent simple explanations.

Data show how humans alter this hydrologic system. Freshwater is withdrawn from the delta for agricultural and urban use, primarily pumping plants in the southwestern delta (Fig. 1). Water exports in WY2006 (8,772 cfs mean flow) were slightly greater than WY2007 (7,972 cfs) despite WY2006 being much wetter not because of

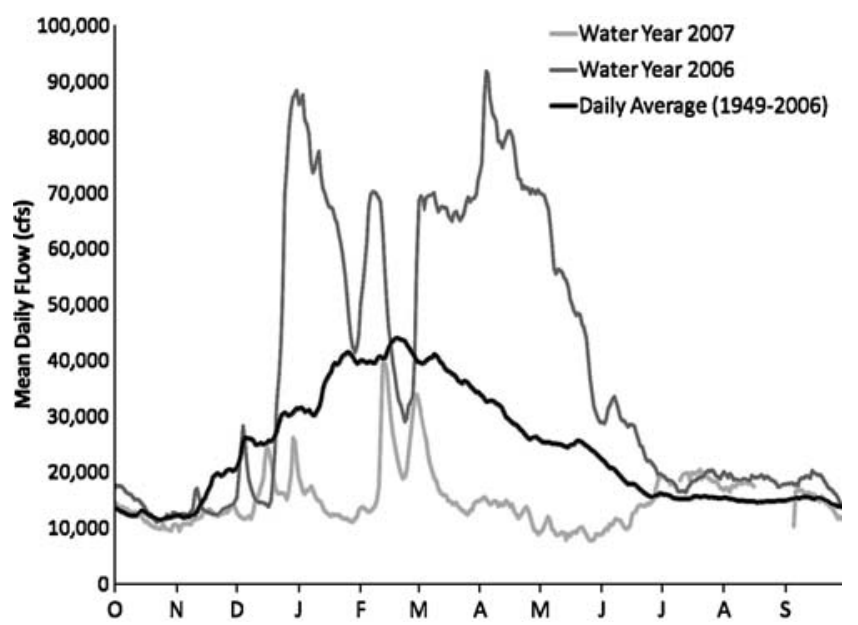

Fig. 6 Mean daily discharge in the Sacramento River at Freeport for water years 2006 and 2007 (Ross 2007). The historical averages from 1949 to 2006 are also shown. Data were obtained from http:// waterdata.usgs.gov/nwis/sw 


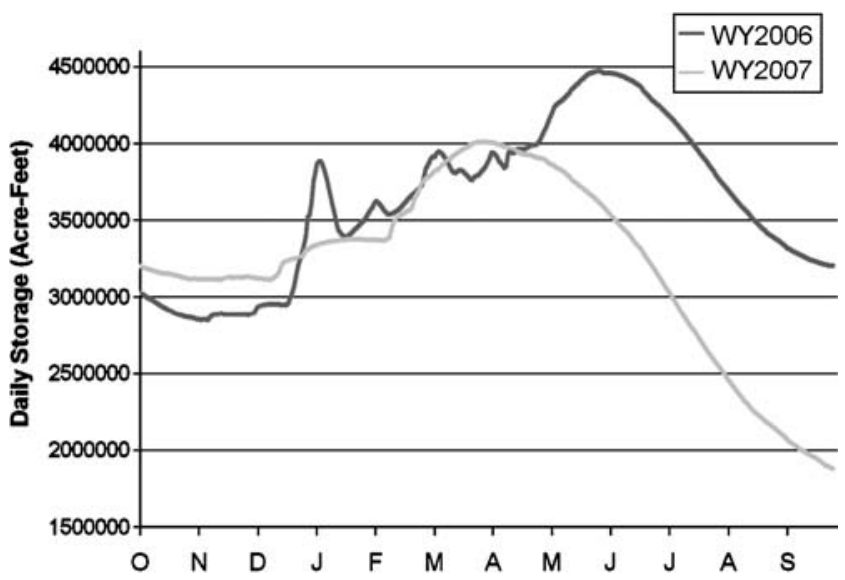

Fig. 7 Water storage behind Shasta Dam (Ross 2007). The dam held approximately 500,000 acre-feet more storage in WY2006 than in WY2007 and peaked later in the year. Data were obtained from http:// cdec.water.ca.gov

precipitation but because reservoir storage was drawn down in WY2007 to make up for below normal precipitation (Figs. 4 and 5) and pumping was restricted in June 2007 to protect fish (Rheinheimer 2007). Tidally averaged mean daily flow from 1987 to 2007 is almost always landward toward diversion pumps at two US Geological Survey gaging stations (Fig. 8, Loboschefsky 2007). During high river flow in 2006, flow was seaward as expected and during dry 2007 flow was landward as is normally the case.

\section{Historical Context}

Comparison of water year data to historical data shows the historical variability of data and places a water year in its historical context. This also makes the students determine what historical data would be most helpful for their readers and how to make a meaningful comparison in limited publication space.

A time frame must be chosen over which to sum time series data for comparison to historical data. Monthly averages were used to compare water year and historical precipitation (Figs. 4 and 5, Carr 2007) and river discharge (Table 2, Zelin 2007). Water year and historical daily river discharges were also compared (Fig. 6, Ross 2007; Fig. 8,
Loboschefsky 2007). Historical and water year annual mean discharges from the 13 gaged local tributaries were compared and time series of the water year and historical mean daily combined flows of the tributaries were plotted to provide historical comparison (Pan 2007). Water year and historical mean annual and mean daily water diversions from the delta were compared (Rheinheimer 2007). Time series data are available at different averaging intervals (typically daily or monthly) and the data source and limitations of students' time available for computing statistical properties determine what averaging interval is presented.

Vertical profile transect data also can be compared to the historical record. Transect data can be presented on a twodimensional plot with a parameter as the dependent variable and two of station, depth, or time specified with the third being the independent variable. For a contour or threedimensional plot, one of station, depth, or time is specified and the other two are independent variables. For the monthly vertical profile transect data available from San Francisco Bay, students generally thought it was best to specify depth and time, make station number (as distance from the southernmost station) the independent variable, and plot water year data as a line and historical data as individual points (Fig. 3, Yang 2007). This shows the longitudinal variability of the parameter during a cruise and the historical longitudinal profile and variability. For example, temperature data in Fig. 4 are surface measurements in July. To show bloom dynamics in subembayments, water year and historical mean surface chlorophyll concentration were plotted as a monthly time series (Fig. 9, Cheng 2007).

\section{Extreme Events}

Extreme events can be identified by comparing water year data with historical data. This can provide clear examples of forcing mechanisms or examples where other factors must have an effect. Explanation of why an extreme event occurred and how it affects the estuary is sometimes trivial and sometimes difficult or impossible.

For example, July water temperatures were at historic highs in 2006 in San Pablo Bay and 2007 in Central Bay

Table 2 Average monthly flow data for water years 2006, 2007, and historical averages (1923-2006) for the San Joaquin River at Vernalis (Zelin 2007)

\begin{tabular}{|c|c|c|c|c|c|c|c|c|c|c|c|c|}
\hline & Oct. & Nov. & Dec. & Jan. & Feb. & Mar. & Apr. & May. & Jun. & Jul. & Aug. & Sep. \\
\hline Historical average flow (cfs) & 2,290 & 2,290 & 3,530 & 5,170 & 7,100 & 7,470 & 7,330 & 7,780 & 6,500 & 2,640 & 1,480 & 1,790 \\
\hline WY 2006 monthly avg. flow (cfs) & 2,619 & 2,038 & 3,521 & 13,170 & 6,458 & 11,700 & 27,940 & 26,050 & 15,690 & 5,547 & 3,697 & 3,316 \\
\hline Percent of historical & $114 \%$ & $89 \%$ & $100 \%$ & $255 \%$ & $91 \%$ & $157 \%$ & $381 \%$ & $335 \%$ & $241 \%$ & $210 \%$ & $250 \%$ & $185 \%$ \\
\hline WY 2007 monthly avg. flow (cfs) & 3,851 & 2,538 & 2,354 & 2,587 & 2,534 & 2,555 & 2,313 & 3,015 & 1,676 & 1,093 & 1,007 & 1,013 \\
\hline Percent of historical & $168 \%$ & $111 \%$ & $67 \%$ & $50 \%$ & $36 \%$ & $34 \%$ & $32 \%$ & $39 \%$ & $26 \%$ & $41 \%$ & $68 \%$ & $57 \%$ \\
\hline
\end{tabular}

Data were obtained from http://waterdata.usgs.gov/nwis/sw 


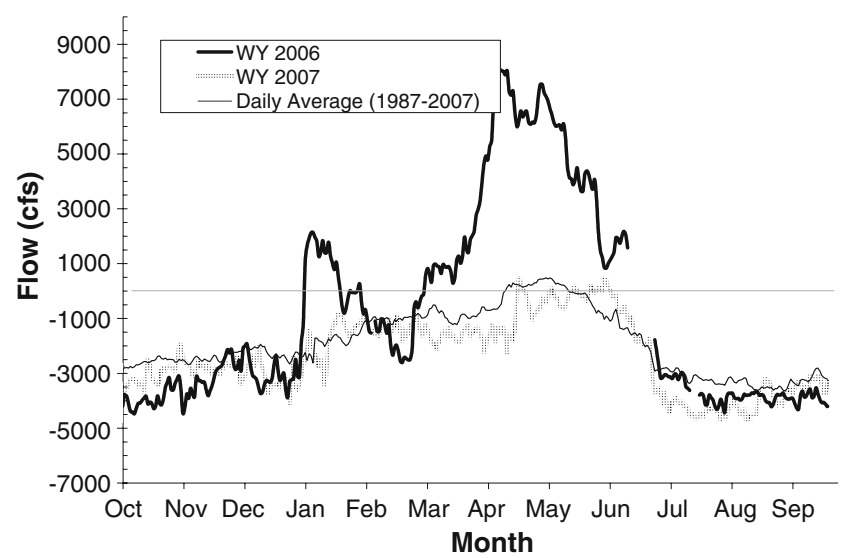

Fig. 8 Tidally averaged flow in Old River at Bacon Island for WY2006, WY2007, and the historical average (Loboschefsky 2007). Positive values are seaward (north). Data were obtained from http:// waterdata.usgs.gov/nwis/sw

(Fig. 3, Yang 2007). In water year 2006, chlorophyll concentrations in the South Bay were at historic highs for the months of February and April (Fig. 9, Cheng 2007).

\section{Scientific Skills}

Regardless of discipline, graduate students must develop a basic set of scientific skills to succeed as scientists. Preparing descriptions of online data exposes students to critical reading of the literature, evaluating data sources and quality, writing and data presentation, and conducting peer review.

Each student is required to obtain and present a paper on their specific topic to the class and lead a class discussion. This seminar portion of the class exposes the students to the current literature and more technical details than I present in lecture. While a common component of graduate classes, this also reinforces the writing and peer review skills. We discuss strengths and weaknesses of the writing and graphics and whether the information presented supports conclusions.

Students gather data from several online data sources which are used by scientists studying San Francisco Bay, its watershed, and the adjacent coastal ocean (Table 1). Some of these data have not been reviewed and some of the data contain apparent errors. So students must evaluate whether the data they have gathered are reliable. The data sources in Table 1 do not contain educationally relevant metadata, which is information about the data specifically for educators (Ledley et al. 2008).

One of the challenges for estuarine scientists and for students is how to present a large data set to an audience while satisfying the conflicting goals of brevity, completeness, accuracy, and understandability. Students must distill a large quantity of data, compute appropriate statistics, make only one or two graphics or tables, and write only two or three paragraphs. Information presented must support any conclusions. The material must be appropriate for the intended audience. Appropriate graphics are essential. The style of graphics will vary depending on the particular data set and what the author is trying to present to their audience. Examples are shown in Figs. 3, 4, 5, 6, 7, 8, and 9.

Peer review is an essential component of science. Constructive yet critical peer review greatly improves science while destructive or lackadaisical peer review either prevents publication of work that should be published or allows publication of work that could be improved or should not be published. This class often exposes graduate students to the peer review process for the first time. Two students review each draft article. As the instructor and editor of the series of articles, I review each draft article and usually offer one or two general comments. The student
Fig. 9 Surface chlorophyll concentration in South Bay plotted for each month of the water year (Cheng 2007). Data were not collected in June 2006, May 2007, June 2007, and August 2007. Data were obtained from http://sfbay.wr.usgs.gov/access/ wqdata/

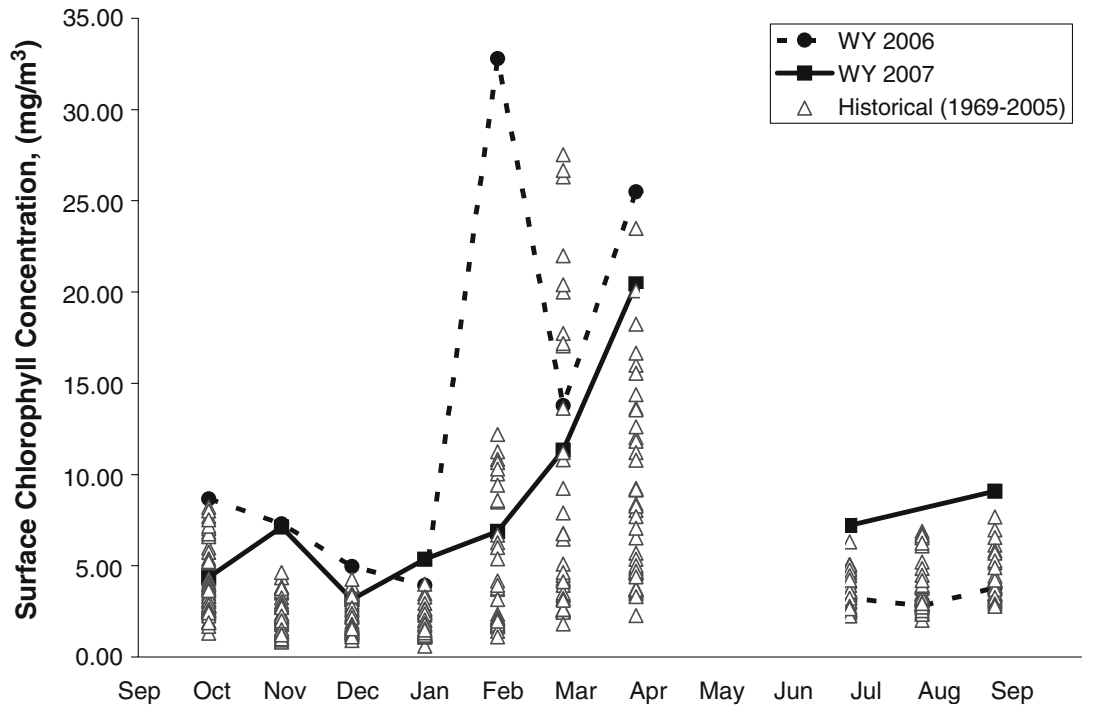


reviews are graded based on the constructiveness, accuracy, and appropriateness of the comments. Providing unwarranted negative comments or making personal attacks result in a low grade. The author responds to the review comments and produces a final draft. The author is graded on the quality of the responses to the reviewers and the quality of the final version.

\section{Conclusion}

The transfigurative development of automated online data sources from estuaries, coastal oceans, and their watersheds provides a tremendous opportunity for educators. In this article, I have presented one approach tailored for San Francisco Bay and its watershed. Different hydrology, data sources, and publication opportunities would necessitate changes if this template were applied elsewhere. Several multidisciplinary hydrologic characteristics are exemplified by typical online data: spatial variability, temporal variability, forcing mechanisms, historical context, and extreme events. The process of writing descriptions of the online data also exposes students to critical reading of the literature, evaluating data sources and quality, writing and data presentation, and conducting peer review.

Acknowledgements I thank the Department of Civil and Environmental Engineering at the University of California, Davis, for the opportunity to teach the class, the students who took the class and wrote the articles referenced here, the editors of Estuaries and Coasts, Jim Cloern and Carlos Duarte, for their invitation to write this article, and Kathryn Kuivila and anonymous reviewers for their helpful comments on earlier versions of this manuscript.

Open Access This article is distributed under the terms of the Creative Commons Attribution Noncommercial License which permits any noncommercial use, distribution, and reproduction in any medium, provided the original author(s) and source are credited.

\section{References}

Bradley, M.P., R. Hanson, and E.S. Walbeck. 2004. Innovative environmental education contributes to improved management practices in the mid-Atlantic region of the United States. Environmental Monitoring and Assessment 94: 205-215.

Carr, K.J. 2007. Precipitation in the San Francisco Bay watershed, water years 2006 and 2007. Interagency Ecological Program Newsletter 20(4): 12-13. http://www.iep.ca.gov/report/newsletter/ 2007_newsletters/IEPNews_fallwinter20072008.final.pdf.

Cheng, M.A. 2007. Chlorophyll in San Francisco Bay, water years 2006 and 2007. Interagency Ecological Program Newsletter 20(4): 30-31. http://www.iep.ca.gov/report/newsletter/2007_newsletters/ IEPNews fallwinter20072008.final.pdf.

Connell, C.R. 2007. Coastal upwelling and sea surface temperature, water years 2006 and 2007. Interagency Ecological Program Newsletter 20(4): 21-22. http://www.iep.ca.gov/report/newsletter/ 2007_newsletters/IEPNews_fallwinter20072008.final.pdf.
Guidice, B.D. 2007. Precipitation in the San Francisco Bay watershed, water year 2005. Interagency Ecological Program Newsletter 20 (3): 10-11. http://www.iep.water.ca.gov/report/newsletter/ 2007_newsletters/IEPNewsletter_FinalSummer2007.pdf.

Hestir, E. 2007. Salinity in the bay and delta, water years 2006 and 2007. Interagency Ecological Program Newsletter 20(4): 24-26. http://www.iep.ca.gov/report/newsletter/2007 newsletters/IEP News fallwinter20072008.final.pdf.

Journet, S. 2007. Suspended sediment in San Francisco Bay and Delta, water year 2005. Interagency Ecological Program Newsletter 20(3): 17-19. http://www.iep.water.ca.gov/report/news letter/2007_newsletters/IEPNewsletter_FinalSummer2007.pdf.

Leatherbarrow, J.E. 2007. Flows in local bay tributaries, water year 2005. Interagency Ecological Program Newsletter 20(3): 13-14. http://www.iep.water.ca.gov/report/newsletter/2007 newsletters/ IEPNewsletter FinalSummer2007.pdf.

Ledley, T.S., A. Prakash, C.A. Manduca, and S. Fox. 2008. Recommendations for making geoscience data accessible and usable in education. Eos 89(32): 291.

Loboschefsky, E. 2007. Delta water flows during water years 2006 and 2007. Interagency Ecological Program Newsletter 20(4): 19-20. http://www.iep.ca.gov/report/newsletter/2007_newsletters/ IEPNews fallwinter20072008.final.pdf.

Noujdina, N. 2007. Water level in San Francisco Bay, water years 2006 and 2007. Interagency Ecological Program Newsletter 20(4): 23-24. http://www.iep.ca.gov/report/newsletter/2007 newsletters/ IEPNews_fallwinter20072008.final.pdf.

Pan, J. 2007. Flow in the San Francisco Bay tributaries, water years 2006 and 2007. Interagency Ecological Program Newsletter 20(4): 16-17. http://www.iep.ca.gov/report/newsletter/2007 newsletters/ IEPNews_fallwinter20072008.final.pdf.

Rheinheimer, D.E. 2007. Diversions from the delta, water years 2006 and 2007. Interagency Ecological Program Newsletter 20(4): 17-19. http://www.iep.ca.gov/report/newsletter/2007 newsletters/ IEPNews_fallwinter20072008.final.pdf.

Ross, K. 2007. Sacramento River flows, water years 2006 and 2007. Interagency Ecological Program Newsletter 20(4): 1315. http://www.iep.ca.gov/report/newsletter/2007_newsletters/ IEPNews fallwinter20072008.final.pdf.

Schoellhamer, D.H. 2007a. Hydrology of San Francisco Bay and Watershed, water year 2005. Interagency Ecological Program Newsletter 20(3): 9-10. http://www.iep.water.ca.gov/report/ newsletter/2007_newsletters/IEPNewsletter_FinalSummer2007. pdf.

Schoellhamer, D.H. 2007b. Hydrology of San Francisco Bay and Watershed, water years 2006 and 2007. Interagency Ecological Program Newsletter 20(4): 10-11. http://www.iep.ca.gov/report/ newsletter/2007_newsletters/IEPNews_fallwinter20072008.final. pdf.

Weathers, T. 2007. San Francisco Bay meteorology: sea level pressure, wind speed, and wind direction for water years 2006 and 2007. Interagency Ecological Program Newsletter 20(4): 22-23. http://www.iep.ca.gov/report/newsletter/2007_newsletters/ IEPNews fallwinter20072008.final.pdf.

White, J.Q. 2007. Suspended sediment in San Francisco Bay and Delta, water years 2006 and 2007. Interagency Ecological Program Newsletter 20(4): 26-28. http://www.iep.ca.gov/report/newsletter/ 2007_newsletters/IEPNews_fallwinter20072008.final.pdf.

Yang, X. 2007 . Water temperature in San Francisco Bay and Delta, water years 2006 and 2007. Interagency Ecological Program Newsletter 20(4): 28-30. http://www.iep.ca.gov/report/newsletter/ 2007 newsletters/IEPNews fallwinter20072008. final.pdf.

Zelin, M. 2007. San Joaquin River Flows, Water Years 2006 and 2007. Interagency Ecological Program Newsletter 20(4): 1516. http://www.iep.ca.gov/report/newsletter/2007_newsletters/ IEPNews_fallwinter20072008.final.pdf. 